\title{
University Governance Case
}

\author{
by Tudor Maxwell \\ (Australia)
}

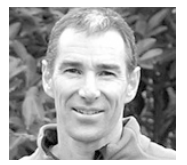

and Stefano Bianchini (Australia)

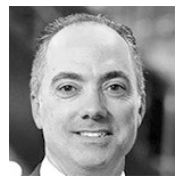

\section{WiseTech Global}

\section{International Center for Corporate Governance}

Ken Dovey (65) had been Director of a Master in Business and Technology (MBT) at a highly regarded university in Sydney, Australia, for 10 years. Under his leadership, the perceived value of the course had improved to the point where it enjoyed the highest student ratings and most engaged alumni of any course offered by that university. But Ken was planning to retire in 2 years, and the benefits of his strong leadership were at risk.

The MBT had been founded (under a different name) as a joint venture between the business and IT faculties, with subjects offered by each department. When Ken took over the leadership of the program, he instituted several changes, notably:

- Stricter screening of applicants to ensure their skill, experience, and commitment were commensurate with the objectives of the MBT (thereby halving the proportion of applicants accepted)

- Tighter controls over the teaching faculty, replacing some academics with industry-based professionals possessing strong academic credentials

- Increasing communication with alumni, students, and teaching staff to build a stronger community around the course

- Cultivating the research culture by focussing a final-year subject on practicebased research (with the option of leading into $\mathrm{PhD}$ studies)

While this strategy lifted the value of the course substantially among the students and alumni, it created tension with administrative leadership in the university:

- Course profitability was negatively impacted by the stricter screening of applicants.

- Members of the business school faculty resented the increased reliance on industry-based professionals and threatened to withdraw support for the use of the word "business" in the course title.

- There were no obvious successors for the role of director in the small full-time teaching faculty. 
Without the support of the university administration, it seemed unlikely that the MBT would be allowed to continue pursuing its strategy, risking deterioration in the qualities that had become important to its reputation.

What advice would you offer to Ken?

\section{$1 \quad$ What Actually Happened?}

Ken recognized the need for succession planning. He also knew that his strongest support bases were in the alumni and students. He therefore aimed to unlock the latent leadership potential in those groups to augment the leadership he was providing to the course.

Ken described the challenge facing the course to the students, alumni, and faculty. When a student (Stefano Bianchini) stepped forward with a proposal to focus on those challenges as part of a course assignment, Ken provided his full support.

Stefano held informal meetings with selected students, alumni, and faculty to secure their involvement in an advisory board made up of representatives of each of those stakeholder groups. He then convened meetings of those representatives, and together they formalized the board and crafted a strategy focussing on:

- Successful leadership transition from Ken

- Increased financial independence through paid consulting and teaching engagements

- Further strengthening the alumni and student community network

- Marketing the course to support an increase in the numbers of high-quality students

Students and alumni volunteered time to execute the strategy. They were motivated by the opportunities to expand their networks, learn from practical leadership activities, and have fun with their peers. The strong leadership exhibited by Stefano (and then two subsequent leaders from the alumni group) was a critical success factor.

Notable successes from board initiatives included a private-sector sponsored C-level golf day (now in its 5th year), consulting and teaching engagements in three large companies, high-quality community events often featuring strong local and international leaders, and the sustained leadership of a toastmasters (public speaking) chapter.

The board progressively improved its status in the university. Notable evidence included:

- The university administration disregarded the protests of the business faculty and supported the use of the "MBT" name for the course (a dramatic shift over 2 years). 
- The administration requested the advice of the MBT advisory board members in an attempt to replicate this model of student and alumni engagement in other faculties.

- The administration engaged MBT board members to provide input on the choice of the director's successor and on how to market the course under new leadership.

New admissions to the course dropped ahead of Ken's departure, as students and alumni anticipated a decline in standards. The new director and administration requested support from the advisory board to use its extensive network to market the course under new leadership. For as long as respect and trust exist between them, the board offers its support willingly. Since it is a voluntary group, though, its support cannot be taken for granted.

\section{What Can We Learn from This Case?}

- Organizations that have benefited from strong leadership for sustained periods may find themselves in crisis when the leader departs.

- Proactive plans to "distribute" leadership ahead of the departure of the incumbent can increase the chance that the organization successfully navigates the transition.

- There are many ways in which people can be motivated to take on a portion of the distributed leadership of an organization-financial incentives may not be essential.

- A degree of isolation from the parent organization may be necessary for institutional innovation of this type to be able to succeed.

Open Access This chapter is licensed under the terms of the Creative Commons Attribution 4.0 International License (http://creativecommons.org/licenses/by/4.0/), which permits use, sharing, adaptation, distribution and reproduction in any medium or format, as long as you give appropriate credit to the original author(s) and the source, provide a link to the Creative Commons licence and indicate if changes were made.

The images or other third party material in this chapter are included in the chapter's Creative Commons licence, unless indicated otherwise in a credit line to the material. If material is not included in the chapter's Creative Commons licence and your intended use is not permitted by statutory regulation or exceeds the permitted use, you will need to obtain permission directly from the copyright holder.

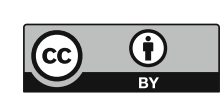

